\title{
Occlusal caries risk assessment using cariogram analysis in student aged 11-12 years
}

\author{
Riana Wardani*, Cucu Zubaedah*, Asty Samiaty Setiawan* \\ ${ }^{*}$ Department of Public Health Dentistry, Universitas Padjadjaran
}

\begin{abstract}
Introduction: Basic Health Research 2013 showed Dental Caries Index in school age student in West Java was lower than the expected target, with occlusal surface as most affected part. The purpose of this study was to determine the risk status of dental caries in school age student by using cariogram analysis. Methods: Observational research study was conducted on 30 student aged 11-12 years with caries high risk on occlusal surfaces. Purposive sampling was taken from students of SDN Cikawari and SDN Mekarjaya Bandung Regency with high DMF-S index. Inclusion criteria: male and female, aged 11-12 years, good systemic health, SDN Mekarjaya and SDN Cikawari Bandung Regency students. Exclusion criteria: suffering from systemic disorder, currently in long-term antibiotic therapy, and orthodontic appliance usage. Case history, eating habits, intake of fluoride, caries experience, salivary volume, and buffering capacity of each sample was examined using cariogram examination method. Results: The cariogram analysis showed $43 \%$ chance of caries avoidance. Diet control was $23.3 \%$, includes two factors: sugary foods and eating frequency. Bacteria control was $11.9 \%$ by evaluating both bacterial factors (the amount of plaque and the bacteria Streptococcus mutans). Vulnerability control was $14.4 \%$, including caries prevention by the continuation of fluorine program and other conditions control that affect salivary secretions. Conclusion: Based on cariogram analysis found that all samples who had occlusal surfaces caries were at a high risk category, but still having moderate potential of avoiding new caries occurrence by controlling risk factors.
\end{abstract}

Keywords: Cariogram analysis, Occlusal caries, Aged $11-12$ years

P-ISSN 1979-0201, e-ISSN 2549-6212 Available from:http://jurnal.unpad.ac.id/pjd/index

DOI:http://dx.doi.org/10.24198/pjd.vol29no1.11344

Submission: Jan 2017 Publishing: March 2017

\section{INTRODUCTION}

Basic Health Research 2013 showed Dental Caries Index in school age student in West Java was lower than the expected target. ${ }^{1}$ Information about dental caries risk status is required in the planning, implementation and evaluation of dental caries prevention. Cariogram method was developed by Bratthall and Hansen ${ }^{2}$ in order to assess the status of an individual's risk of dental caries. Cariogram method was introduced as a simple and user friendly assessment method of a person's caries risk status. ${ }^{2}$ By knowing the level of each individual's risk of dental caries, prevention 
program can then be designed according to each needs. In order to determine whether a person has a high or low caries risk, it is necessary to do a series of examination or evaluation in order to identify any risk factors that play a role in increasing the risk of dental caries. ${ }^{3}$

Caries risk factors can be discovered from the anamnesis results, medical record examination, clinical examination and laboratory tests. The anamnesis results and medical record examination obtain individual socioeconomic status, race and culture, bad habits, diet, case history, dental care, and treatment history. The clinical examination, and laboratory tests obtain a number of caries factors such as, the composition and morphology of the teeth, the severity of caries, the amount and quality of restorations, the use of orthodontic appliances, the level of Streptococcus mutans and Lactobacilli, and also the conditions of saliva $(\mathrm{pH}$, secretion speed, and buffer capacity). From the results of risk factors evaluation, obtain two groups of caries risk, high risk, and low risk. ${ }^{3}$ By knowing the status of the risk of caries, a dental health practicioner can develop a model of health promotion and prevention of caries through caries risk factor control. Control of risk factors for dental caries is a particular part of prevention efforts in resolving dental caries as recommended by WHO.4,5 Environmental and socioeconomic factors influence dental health of children. Low socioeconomic milieu will resulted in low dental and oral hygiene which were predisposing factors that cause caries.

Based on the location of the occurrence, caries was divided into two types, caries on the pits and fissures, and caries on smooth surface of teeth. ${ }^{6}$ Occlusal surface is the most affected part by caries, while the buccal surface of upper jaw teeth and the lingual surface of lower jaw teeth are the most rare part affected by caries. ${ }^{7}$

Indonesia Oral Health Profile Report stated that caries in children having the highest prevalence due to childern age between 6-12 years or school-age children, because of knowledge and understanding regarding the maintenance of oral hygiene. The results of the data was consistent with the results of Household Health Survey in 2001 that there were $76.2 \%$ of Indonesian student in the age group of 12 years old suffered from dental caries, while in West Java $85 \%$ of schoolage student suffered from the disease. ${ }^{8,9}$

Before caries spread to all parts of the teeth, caries will occur on partial surfaces of the teeth. Surfaces that were affected by caries could be viewed by using the DMF-S index. DMF-S index was used to calculate the index of decayed, missing, and filling in permanent teeth of each tooth surface, so that we can see the most affected part. ${ }^{10}$

From the results of previous PUPT research first phase in 2015 conducted by Wardani, et al. ${ }^{11}$ on 90 students aged 11-12 years in the same elementary schools discovered that the average number of surface cavities (decayed) was 3.83 surfaces. The most affected surface by caries was the occlusal surface with the number of 226 surfaces, while the mesial surface was rarely affected by the caries with the number of 17 surfaces. The number of Streptococcus mutans was as follow: in the negative category was $90 \%$ and positive category was $10 \%$, while saliva $\mathrm{pH}$ was $46.7 \%$ and included in acidic category. ${ }^{11}$ The purpose of this study was to determine the risk status of dental caries in school age student by using cariogram analysis.

\section{METHODS}

The study was conducted on 30 student aged 11-12 years with caries on occlusal surfaces in Bandung during period of 2015-2016. The methods used was observational research, refers to selfreliance research on the comprehensive oral diseases management. The sampling method used was purposive sampling, with sample students of SDN Cikawari and SDN Mekarjaya Bandung Regency with DMF-S index higher than the population. Inclusion criteria were male and female, aged 11-12 years, good systemic health; and exclusion criteria were suffering from systemic disorder, currently in long-term antibiotic therapy and orthodontic appliance usage. The age of 11-12 years were used as indicators in monitoring caries (global monitoring age). This was because at the age of 12 years all permanent teeth have been erupted, except for the third molar.

Caries risk assesment was conducted using cariogram analysis. A number of questions were 


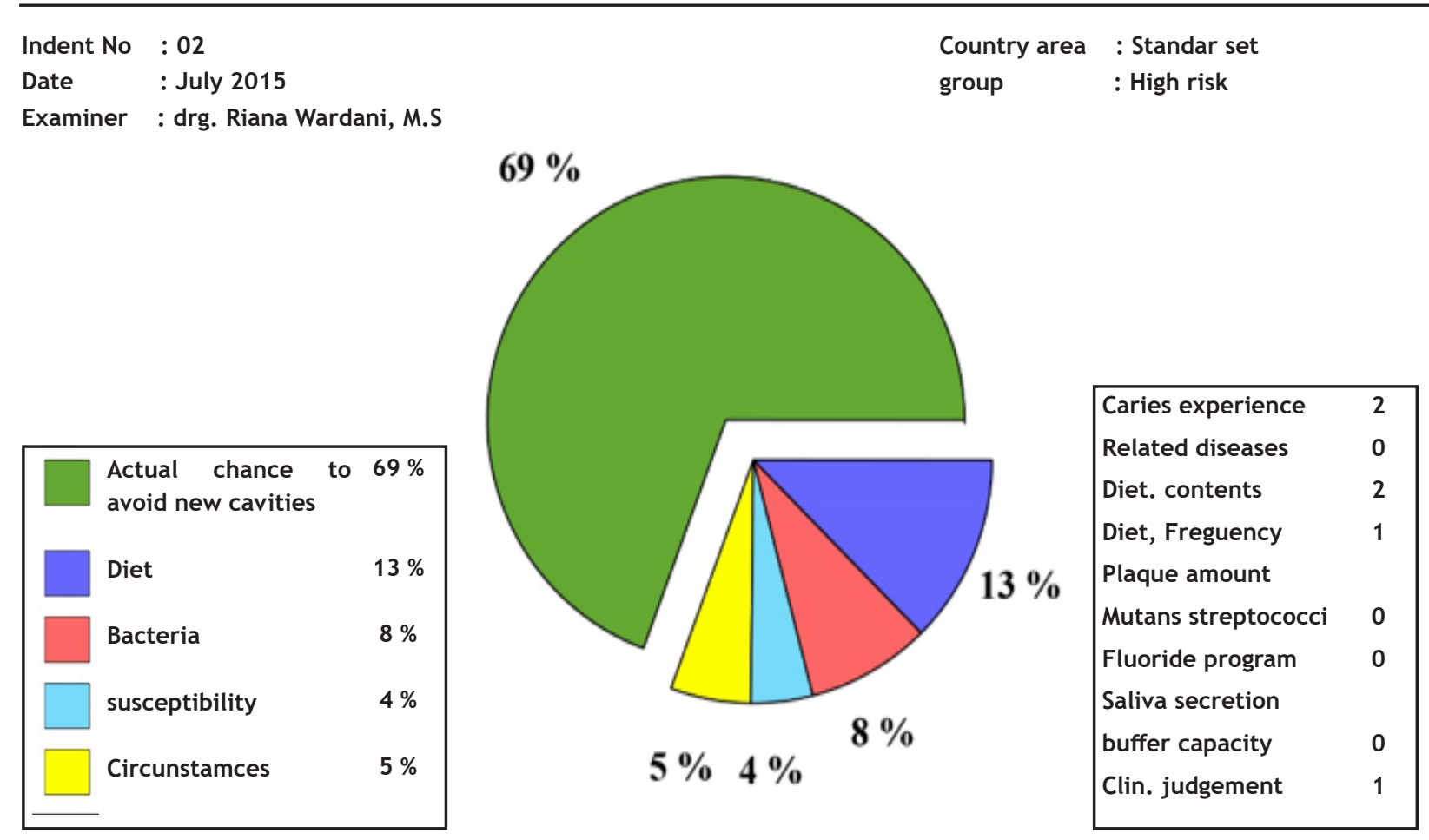

Figure 1. Example of cariogram of caries risk factor analysis

asked to a sample for case history, eating habits and intake of fluoride. Furthermore, examination to determine the caries experience, the amount of plaque, saliva volume, and buffering capacity of saliva was conducted according to cariogram examination method. Cariogram program contains 10 chargeable parameters, score $0-3$ was given in the box provided by using the arrow up or down, under the circumstances that score 0 is the best score and score 3 is the worst score. The percentage of the risk factor would be shown according to the answer inputted to the box. Green sector is an opportunity to prevent new caries. When the green sector is $20 \%$ or less indicates a high caries risk. Figure 1 explain about example of cariogram of caries risk factor analysis.

\section{RESULTS}

Interview and examination conducted towards 30 male and female students of SDN Mekarjaya and SDN Cikawiri Bandung Regency. On examination of 319 decay surfaces found that 226 caries occured on occlusal surfaces.

Based on interview and examination results also found that cariogenic food consumed was $96.3 \%$. Student's cariogenic food eating frequency was $60 \%$ often and very often. Gum conditions $56.7 \%$ included to good category and $93.4 \%$ students using fluoride toothpaste. Respondent's case history were healthy according to requirements of not having systemic disorder, not in the long term antibiotic therapy, and not using any orthodontic appliance.

The results of risk factors based on cariogram analysis produced two groups high risk level and low-risk level for each individual with the following criteria: The group with the status of high-very high risk having the opportunity to avoid new caries $<40 \%$, and group with the status fair-rather low risk having the opportunity to avoid new caries $>40 \%$.

The cariogram analysis also showed $43 \%$ chance of caries avoidance. Diet control was $23.3 \%$, includes two factors: sugary foods and eating frequency. Bacteria control was $11.9 \%$ by evaluating both bacterial factors (the amount of plaque and the bacteria Streptococcus mutans). Vulnerability control was $14.4 \%$, including caries prevention by the continuation of fluorine program and other conditions control that affect salivary secretions.

Cariogram data result of subject of study presented in Table 1, and the results of risk factors categorized in Table 2. Table 3 explained about mean of risk factor category after analyzed using cariogram. 
Table 1. Cariogram data of 11-12 years of age student of SDN Mekarjaya dan SDN Cikawiri

\begin{tabular}{|c|c|c|c|c|c|c|}
\hline Respondence & Chance to avoid new caries & Diet & Bacteria & Vulnerability & Other condition & Risk factor \\
\hline 1 & 22 & 38 & 15 & 15 & 10 & High \\
\hline 2 & 69 & 13 & 8 & 4 & 5 & Fair \\
\hline 3 & 9 & 37 & 15 & 30 & 10 & Very high \\
\hline 4 & 19 & 36 & 14 & 21 & 9 & Very high \\
\hline 5 & 47 & 24 & 10 & 10 & 9 & Moderate \\
\hline 6 & 62 & 12 & 12 & 8 & 5 & Fair \\
\hline 7 & 25 & 39 & 23 & 8 & 5 & High \\
\hline 8 & 51 & 25 & 10 & 5 & 10 & Moderate \\
\hline 9 & 7 & 19 & 8 & 62 & 5 & Very high \\
\hline 10 & 23 & 40 & 16 & 16 & 5 & High \\
\hline 11 & 77 & 7 & 5 & 7 & 3 & Fair \\
\hline 12 & 75 & 15 & 6 & 3 & 2 & Fair \\
\hline 13 & 59 & 9 & 9 & 14 & 9 & Moderate \\
\hline 14 & 28 & 22 & 15 & 22 & 14 & High \\
\hline 15 & 26 & 31 & 15 & 23 & 5 & High \\
\hline 16 & 21 & 36 & 15 & 15 & 14 & High \\
\hline 17 & 53 & 18 & 9 & 14 & 6 & Moderate \\
\hline 18 & 41 & 9 & 18 & 27 & 6 & Moderate \\
\hline 19 & 75 & 15 & 6 & 3 & 2 & Fair \\
\hline 20 & 11 & 41 & 14 & 21 & 13 & Very high \\
\hline 21 & 53 & 18 & 9 & 14 & 6 & Moderate \\
\hline 22 & 40 & 25 & 17 & 8 & 11 & High \\
\hline 23 & 84 & 7 & 3 & 5 & 1 & Low \\
\hline 24 & 69 & 13 & 8 & 4 & 5 & Fair \\
\hline 25 & 62 & 13 & 9 & 9 & 8 & Fair \\
\hline 26 & 33 & 35 & 17 & 9 & 6 & High \\
\hline 27 & 51 & 18 & 9 & 13 & 9 & Moderate \\
\hline 28 & 30 & 23 & 15 & 23 & 10 & High \\
\hline 29 & 42 & 22 & 13 & 13 & 9 & Moderate \\
\hline 30 & 25 & 40 & 16 & 8 & 10 & High \\
\hline
\end{tabular}

Table 2. Risk factors category based on individual cariogram of 11-12 years old student of SDN Mekarjaya dan SDN Cikawiri

\begin{tabular}{lcc}
\hline \multicolumn{1}{c}{ Risk factor } & Frequency & Persentation \\
\hline Very High & 4 & 13.3 \\
High & 10 & 33.4 \\
Moderate & 8 & 26.7 \\
Fair & 7 & 23.3 \\
Low & 1 & 3.3 \\
\hline Total & 30 & 100 \\
\hline
\end{tabular}

\section{DISCUSSION}

Basic Health Research 2013 showed that the Indonesian caries prevalence was $72.6 \%$, with only $31.1 \%$ individual got oral care and treatment,
Table 3. Mean of caries risk category in 11-12 years old student of SDN Mekarjaya dan SDN Cikawiri

\begin{tabular}{lc}
\hline \multicolumn{1}{c}{ Risk category } & Persentation (\%) \\
\hline Chance to avoid new caries & 43 \\
Diet & 23.3 \\
Bacteria & 11.9 \\
Vulnerability & 14.4 \\
Other conditions & 7.4 \\
\hline \multicolumn{1}{c}{ Total } & 100 \\
\hline
\end{tabular}

and Decay, Missing, Filled-Teeth (DMF-T) index inclination was 4.5 DMF-T index on 11-12 years old children was 1.38 , whilst WHO targeting DMF-T on 11-12 years old children $\leq 1$ on Global Goals for Oral Health 2020. ${ }^{12}$ The data showed that oral 
health problem in Indonesia was still on the high level. From the same research also obtained that in West Java, Dental Caries Index of school age student even lower than the expected target. ${ }^{1}$

Dental caries is a process that involves many factors. The mechanism of dental caries involves the interaction between the four factors, microorganisms, substrate, teeth, and saliva, as well as time. Tooth morphology is also one of the host factors of dental caries.

Caries risk factors can be discovered from the anamnesis results, medical record examination, clinical examination, and laboratory tests. The anamnesis results and medical record examination obtain individual socioeconomic status, race and culture, bad habits, diet, case history, dental care, and treatment history. The clinical examination and laboratory tests obtain a number of caries factors such as, the composition and morphology of the teeth, the severity of caries, the amount and quality of restorations, the use of orthodontic appliances, the level of Streptococcus mutans and Lactobacilli, and also the conditions of saliva $(\mathrm{pH}$, secretion speed, buffer capacity). From the results of risk factors evaluation, obtain two groups of caries risk, high risk and low risk. ${ }^{3}$ By knowing the status of the risk of caries, a dental health practicioner can develop a model of health promotion and prevention of caries through caries risk factor control. Control of risk factors for dental caries is a particular part of prevention efforts in resolving dental caries as recommended by WHO. ${ }^{4,5}$ Environmental and socioeconomic factors influenced dental health of children. Low socioeconomic milieu will resulted in low dental and oral hygiene which were predisposing factors that cause caries.

Based on the location of the occurrence, caries was divided into two types, caries on the pits and fissures and caries on smooth surface of teeth. ${ }^{6}$ Occlusal surface is the most affected part by caries, while the buccal surface of upper jaw teeth and the lingual surface of lower jaw teeth are the most rare part affected by caries. ${ }^{7}$

Before caries spread to all parts of the teeth, caries will occur on partial surfaces of the teeth. Surfaces that were affected by caries could be viewed by using the DMF-S index. DMF-S index was used to calculate the index of decayed, missing, and filling in permanent teeth of each tooth surface, so that we can see the most affected part. ${ }^{10}$

According to research conducted in Istambul by Demirci, ${ }^{13} 62.4 \%$ of caries distribution was in the maxillary jaw and approximal surfaces of all teeth had the highest caries rates, ranging from $58.5 \%$ to $77.5 \%$. Occlusal surfaces of the teeth more vulnerable to caries compared with other surfaces, because of the distinctive shape makes it difficult to clean. Tooth with deep pits and fissure also more vulnerable to caries, because plaque and microorganisms will stick to tooth's pit and fissure teeth and also difficult to clean. ${ }^{14}$ Teeth composition also affects the occurrence of caries. Crowding teeth will also cause difficulties in tooth cleaning, thereby increasing the occurrence of caries and other periodontal diseases.

The function of saliva is as a lubricant, protective buffer (buffer saliva), cleansing, antibacterial and anti-solvent. However, saliva plays an important role in the process of plaque formation, and also as a life medium of microorganisms. There are still dissenting opinions about the relationship between caries frequency and factors inside saliva such as, saliva buffer, chemical composition, flow, viscosity, and anti-bacterial factor.

Various types of oral microorganisms that can be associated with caries including various strains of Streptococci, Lactobacilli, and others. Several research have proved that Streptococcus contribute to dental caries and related to carbohydrates, dental plaque, saliva, and mostly found inside oral cavity and tooth surfaces. Microorganisms attached to the teeth because the presence of plaque, that is malleable material attached tightly to the teeth and consists of microorganisms (70\%) and materials between cells. Among all plaque microorganisms, Streptococcus mutans has the highest ability to ferment sucrose and form lactic acid.

Sucrose has the highest cariogenic potential especially for smooth surfaces and is the most widely used sugar in diet. The result of the metabolism of sucrose by cariogenic microorganisms, especially Streptococcus mutans is extra cellular polysaccharide which is instru mental in the formation of dental plaque. This increase the possibility of plaque adhesion on the smooth enamel surface. Glucose metabolism by Streptococcus mutans through glycosyl transferase 
produce lactic acid and energy required by microorganisms to proliferate inside the plaque. Energy and lactic acid will continue to formed as long as there sucrose, so that the $\mathrm{pH}$ of the plaque will remain low for a long time. Bacteria is instrumental in the process of caries because of its ability to produce dental plaque form sucrose. Inside the plaque, colonies of bacteria will form acid from dietary carbohydrates, causing demineralization of tooth enamel. Therefore, dental caries activity can be assessed by counting the number of colonies of Streptococcus mutans inside dental plaque and also decrease of saliva $\mathrm{pH}$. Germination in order to count the number of Streptococcus mutans colonies can be done in TYCS20B (Trypticase Yeast Cystine Sucrose 20 Bacitracin) on anaereob conditions for 48 hours at $37^{\circ} \mathrm{C}$ and will be obtained colonies that formed limpid "halo". ${ }^{15}$ Streptococcus mutans blood must performed beta hemolysis and reacted positively with eskulin, lactose, sucrose, mannitol, sorbitol, inulin and rafinose. ${ }^{15}$

Indonesia Oral Health Profile Report stated that caries in children having the highest prevalence due to children aged between 6-12 years or school-age children lack of knowledge and understanding regarding the maintenance of oral hygiene. The results of the data was consistent with the results of Household Health Survey in 2001 that there were $76.2 \%$ of Indonesian student in the age group of 12 years old suffered from dental caries, while in West Java $85 \%$ of schoolage student suffered from the disease. ${ }^{8,9}$

From the results of previous PUPT research first phase in 2015 conducted by Wardani et al. on 90 students aged 11-12 years in the same elementary schools discovered that the average number of surface cavities (decayed) was 3.83. The most affected surface by caries was the occlusal surface with the number of 226 surfaces, while the mesial surface was rarely affected by the caries with the number of 17 surfaces. The number of Streptococcus mutans was as follow: in the negative category $(90 \%)$ and positive category $(10 \%)$, while saliva $\mathrm{pH}$ was $46.7 \%$ and included in acidic category. ${ }^{11}$

Early detection of initial caries lesions and the preventive approach are the main aims for maintaining a good oral health status. ${ }^{16}$ Cariesrisk assessment is an essential procedure for dentists in decision-making processes concerning treatment, and recall appointments, and in determining the need for additional diagnostic procedures. ${ }^{17}$ The common practice is to assess these factors individually and also, as dental caries is a multifactorial disease, more than one factor can predict future caries. Therefore, the use of validated instruments for guiding the professional in establishing the risk profile of a patient is essential. ${ }^{18}$

Several risk prediction and risk assessment models were developed, and multifactorial modeling was used to increase the accuracy of risk assessments. The ideal risk assessment model should be easy to use, and the process should not be time-consuming in clinical practice. The outcome should be understandable, so it can be used as a didactic tool for patient education and motivation. ${ }^{19}$

Cariogram is one of the most reliable caries risk assessment models, because it is a truly comprehensive and objective method based on quantitative data of an individual. ${ }^{19}$ In addition, the model not only performs a caries risk assessment but also includes suggestions for preventive and clinical actions. Because changing patient behaviors has become the cornerstone of preventive treatment, advice about problems should be individualized, and patient awareness should be raised. ${ }^{20}$ Thus, cariogram is a helpful tool for patient education and motivation, and also for dentists in clinical decision-making processes. Caries-risk assessment of communities allows high-caries-risk groups and treatment needs to be determined, so preventive applications can be carried out. In order to determine whether a person has a high or low caries risk, it is necessary to do a series of examination or evaluation in order to identify any risk factors that play a role in increasing the risk of dental caries. ${ }^{3}$

Based on interview and examination towards 30 male and female 11-12 years old students of SDN Mekarjaya and SDN Cikawiri Bandung Regency found 319 decay surfaces found that 226 caries occured on occlusal surfaces. This is likely due to the difficulty of cleaning the teeth in such part, and also because of the lack of knowledge of children aged 11-12 years about oral hygiene. According to research conducted by Togoo et al. ${ }^{21}$ about the prevalence of the first permanent molar caries, also stated that the occlusal surface of 
first permanent molars became the most location of the dental caries after eruption.

This research also found that cariogenic food consumed by students was $96.3 \%$ from all diet. Student's cariogenic food eating frequency was $60 \%$ often and very often. Gum conditions $56.7 \%$ included to good category and $93.4 \%$ students using fluorine toothpaste. It is understandable why the sample of this study classified into the high risk of dental caries category, because one of determining caries factors, cariogenic food, becoming the most consumed food in high frequency. As found in Somasundaram et al. ${ }^{22}$ research that children who watched television advertisements about potentially cariogenic food and used to eat them were found to have more caries index.

However, the cariogram analysis showed $43 \%$ chance of caries avoidance. With diet control was $23.3 \%$, includes two factors: sugary foods and eating frequency. Bacteria control was $11.9 \%$ by evaluating both bacterial factors (the amount of plaque and the bacteria Streptococcus mutans). Vulnerability control was $14.4 \%$, including caries prevention by the continuation of fluorine program and other conditions control that affect salivary secretions.

This means that a chance to avoid new caries still medium potential level. Because the prevention of dental caries can be done by controlling the risk factors such as diet, bacteria, vulnerability factors and other circumstances. Also in accordance with Renuka ${ }^{23}$ research which stated that analysis about caries risk factor by using cariogram could be used as an effective health educational tool in changing the parents/ caregivers attitude and behaviours in order to obtaining the good oral hygiene and dietary habit maintenance, and there was significant reduction in caries risk after six weeks of intervention in all subjects in the form of personally based caries risk factor control treatment. ${ }^{23}$

By knowing the status of caries risk, the dental profession can develop a model of health promotion in the form of counseling about how to maintain oral health and caries prevention through the control of risk factors for caries in children such as, the application of fluorine, closing loopholes/curvatures on the surface of the teeth (fissure sealant), so the prevalence of caries can be reduced and obtaining the improvement of oral health. ${ }^{24}$

As found in research conducted by Hurlbutt ${ }^{25}$ about caries management by risk assessment (CAMBRA), an evidence-based approach to preventing or treating dental caries at the earliest stages. Caries protective factors are biologic or therapeutic measures that can be used to prevent or arrest the pathologic challenges posed by the caries risk factors. Best practices dictate that once the clinician has identified the patient's caries risk (low, moderate, high or extreme), and the personal caries risk factor potential measurement by using personal measurement tool such as cariogram, a therapeutic and/or preventive plan implemented. ${ }^{25}$

\section{CONCLUSION}

Based on the cariogram analysis found that 11 . 12 years old students of SDN Mekarjaya and SDN Cikawiri Bandung Regency who had occlusal surfaces caries were at a high risk category, but still having moderate potential of avoiding new caries occurrence by controlling risk factors.

\section{ACKNOWLEDGEMENT}

This study was funded by Research and Community Services Director, Universitas Padjadjaran.

\section{REFERENCES}

1. National Basic Health Research (RISKESDAS) Dental health. Jakarta: The National Institute of Health Research and Development Ministry of Health Republic of Indonesia; 2013. p. 142.

2. Bratthall D, Petersson HG. Cariogram - A multifactorial risk assessment model for a multifactorial disease. Community Dent Oral Epidemiol 2005;33:256-64.

3. Chandra S, Chandra S. Textbook of preventive dentistry. New Delhi: Jaypee Brothers Medical Publisher; 2008. p. 20-105.

4. WHO. World health for a healthy life. Geneva: WHO library cataloguing data; 1994.

5. Sundoro EH. Pendekatan preventif dalam penanggulangan karies. Jakarta: Jurnal Kedokteran Gigi Universitas Indonesia 2000;7 (Edisi Khusus):412-16. 
6. Kidd EAM, Joyston-Bechel S. Essentials of dental caries: The disease and its management. $2^{\text {nd }}$ ed. Oxford: Oxford University Press; 1997.

7. Murray, Nunn. Prevention of oral disease. Oxford: University Press; 2003. p. 272.

8. Depkes RI. Profil Kesehatan gigi dan mulut di Indonesia. Jakarta: Dirjen Pelayanan Medik; 2006. p. 59.

9. National Household Health Survey (SURKESNAS) Jakarta: Ministry of Health Republic of Indonesia; 2001.

10. Hiremath SS. Textbook of preventive and community dentistry. $2^{\text {nd }}$ ed. New Delhi: Elsevier; 2011. p. 182-96.

11. Wardani R, Zubaedah C, Samiaty A. Salivary $\mathrm{PH}$ and bacterial count assesment in children with high caries risk. Proceedings of The 17th Scientific meeting and Refresher Course in Dentistry. Jakarta: KPPIKG Faculty of dentistry Universitas Indonesia; 2016. p. 14-5.

12. Rencana aksi nasional pelayanan kesehatan gigi dan mulut tahun 2015-2019. Jakarta: PDGI; 2015. p. 12-3.

13. Demirici M, Tuncer S, Yucoecur A. Prevalence of caries on individual tooth surface and its distribution by age and gender in university clinic patients. Eur J Dentistry 2010;4:270-9.

14. Featherstone JDB. Prevention and reversal based on the caries balance. Pedriatic Dent 2006 Mar-apr;28(2):128-32.

15. Roeslan BO. Karakteristik Streptococcus mutans penyebab karies gigi. Majalah IImiah FKG Usakti 1995;10(29-30):112-25.

16. Kassawara $A B$, Tagliaferro EP, Cortelazzi KL, Ambrosano GM, Assaf AV, Meneghim Mde C, et al. Epidemiological assessment of predictors of caries increment in 7-10 year olds: a 2-year cohort study. J Appl Oral Sci 2010;18:116-20.

17. Twetman S, Fontana M. Patient caries risk assessment. Monogr Oral Sci 2009;21:91-101. (E-pub 2009 Jun 3).

18. Cabral RN, Hilgert LA, Faber J, Leal SC. Caries risk assessment in schoolchildren-a form based on Cariogram ${ }^{\circledR}$ software. J Appl Oral Sci; 20140ct;22(5):397-422.

19. Ilkay P, Mangal T, Erten H, Alp G, Avci E, Akca $G$, et al. Evaluation of caries risk in a young adult population using a computer-based risk assessment model (Cariogram). J Dent Scie 2012;7(2):99-104.

20. Kidd EA. Assessment of caries risk (review). Dent Update 1998;25:385-90.

21. Togoo RA, Yaseen SM, Lall S, Algarni FAS, Faraj A, Shah FK. Prevalence of the first permanent molar caries among 7-10 years old going boys in Abha City, Saudi Arabia. Bangladesh J Med Scie 2012;11:98-102.

22. Somasundaram R. Rangeeth BN, Joyson $M$, Sivakumar S. Comparison of the source of Introduction to cariogenic food substance and caries prevalence in children. $\mathrm{J}$ Clin Diagn Res 2014 Nov;8(11):ZC138-40.

23. Renuka P, Pushpanjali K. Cariogram as an educational tool for reducing the caries risk among the differently abled children-case series. IOSR J Dent Med Scie 2015;14(4):60-7.

24. Pintauli $S$, Hamada T. Menuju gigi dan mulut sehat, pencegahan dan pemeliharaan; karies gigi. Medan: USU Press; 2008. p. 4-80.

25. Hurlbutt M. CAMBRA: Best practices in dental caries management. Registered Dental Hygienist Magazine. October 2011. p. 96-97. 